\title{
Physicochemical and Biological Characteristics of Aloe Barbadensis Miller Gel Extract from Ghardaia, Algeria
}

\author{
Yasmina khane ${ }^{1,2}$, Tahri Ahmed ${ }^{3}$, Benouis Khedidja ${ }^{4}$, Dabouz Mounir ${ }^{1}$, Chihani \\ Salah $^{1}$, Khane sofiane ${ }^{5}$. \\ ${ }^{1}$ Université de Ghardaia, B.P 455, Ghardaïa, Algerie \\ ${ }^{2}$ Laboratoire de chimie appliqué, ACTR Univ Ain Temouchent/ DGRCT, Bp 284, 46000 Ain Temouchent \\ ${ }^{3}$ Unité de Recherche en Energie Renouvelable en Milieu Saharien, URERMs, Centre de Développement des Energies \\ Renovlables, CDER, Adrar, Algeria. \\ ${ }^{4}$ Laboratory of process engineering, materials and environment, department of Energy and Process Engineering, \\ Faculty of Technology, university of Djillali Liabes, Sidi Bel Abbes, PO Box89 SBA 22000 -Algeria \\ ${ }^{5}$ Université Djillali Liabès, BP 89 arbi ben m'hidi, Sidi Bel-Abbès 22000.
}

"Corresponding author. Email: yasminekhane@yahoo.fr or khane.yasmina@univ-ghardaia.dz

\begin{abstract}
Aloe barbadensis Miller, usually referred to Aloe vera, has existed around since the dawn of time. It is a North African plant that has a variety of medicinal properties. This work was a contribution to studying the physico-chemical characteristics, the photochemical content, and the biological properties of Aloe Barbadensis Miller, a plant collected from a local garden located in the small town of Berriane (region of Ghardaïa, Algeria). The antioxidant activity was determined utilizing the DPPH method, and the solid medium diffusion method was employed to assess the antimicrobial potential against human pathogenic bacteria a gram positive (S. aureus) bacterial strain, two gram negative bacteria (E. coli and P. aeruginosa), and one yeast (Candida albicans) and fungi. The phytochemical analysis demonstrated the existence of different phytochemical substances such as phenol, flavonoid, tannin, alkaloid, saponin, and terpenoid in aloe vera gel extract. Furthermore, the antibacterial test of Aloe vera leaf extracts revealed that the gram negative bacteria $E$. coli sensibility compared with the two other bacteria ( $S$. aureus and $P$. aeruginosa), which showed resistance, and that this extract showed antifungal efficiency against the fungi. In addition, the aloe vera extract was given an antioxidant effect according to the DPPH free radical method. The findings of this study allowed us to confirm that Aloe vera's biological activity is principally due to the existence of various phytochemical compounds with biological activities, like phenolic compounds. According to these obtained results, A. barbadensis gel extract can be utilized to treat certain diseases by providing a natural biological active component.
\end{abstract}

Keywords: Aloe vera; total polyphenols, flavonoids, antioxidant activity, antimicrobial.

\section{INTRODUCTION}

Since ancient times, medicinal plants with ethnobotanical significance have been used as the most important source for finding pharmaceutical substances to cure various diseases and health problems [1]. Aloe is a genus within the Liliaceae family, is found all over the world with almost 500 species, with very different sizes and aspects $[2,3]$.

The specie Aloe Barbadensis Miller, also recognized by the names Aloe vera Linne, Barbados or Curaçao Aloe, is endemic to northern Africa and cultivates in arid and subtropical climates [4]. It's a perennial succulent or xerophyte short stem with elongated and pointed green fleshy leaves that can grow from a few centimeters to more than 2-3 meters high and containing three different layers and storing lots of water. The firs thick membrane is the protective layer for filter air and water and accounts for around $20 \%$ to $30 \%$ of its total weight, which contains more than 18 cell layers that are interleaved with chloroplasts, which produced the carbohydrates, lipids, and proteins $[5,6]$. Then there's the cellulose derme layer, 
which has laxitive properties and is known as aloe's "blood." Finally, there's the transparent parenchyma, which is the gel that the plant is looking for. The characteristics of this gel are mostly influenced by the soil and environmental conditions [7].

Aloe Barbadensis Miller is the most popular variety and is often employed not just for decoration but also to make a variety of therapeutic compounds to treat skin and digestive problems due to the plant's abundance of bioactive secondary metabolites [8] [9]. Aloe vera is utilized as a supplemental health ingredient and preservative in a wide variety of food products [10] [11]. It serves as an important source of pharmacological ingredients used in a number of medical applications, such as bactericidal [14] [15], antifungal [16], antiviral [17], anti-inflammatory [18, 19], antioxidant [20] anticancer [21], antitumor [22], cytotoxic [23], and so on. It's also been used to treat burn wounds ranging from first to second degree [24] [26], radiation dermatitis [27], and skin problems [28, 29], as well as cure for diabetes diseases due to its antidiabetic proprieties [30], to treat cardiovascular illness and to improve the immune system [31].

The fresh Aloe vera $L$. gel is composed of $99.1 \%$ of water and $0.9 \%$ dry matter, which includes $16.2 \%$ of cell wall, $0.7 \%$ of microparticles, and $83.1 \%$ of liquid gel [4]. Recent studies reveal that Aloe vera gel contains a wide variety of photochemical compositions like phenolic acids, flavonoids, salicylic acids, stilbenes, anthraquinones, coumarins, phytosterols, saponins, other constituents as amino acids, glycoproteins, enzymes, polysaccharides, vitamins, and minerals [5] [6] [10][13] [31-35].

The purpose of our study is to establish the phytochemical compositions of local Aleo vera gel extract and investigate their antioxidant and antimicrobial capacity.

\section{MATERIALS AND METHODS}

\subsection{Preparation of Aloe vera gel extract}

On February 28, 2021, Aloe Barbadensis Miller L. fresh leaves were harvested by hand, randomly, on the same plant, from a local garden located in Berriane, a small town in the city of Ghardaiia (Algeria) (Fig. 1). This area has a Saharan climate characterized by a cold winter and a hot and dry summer, with temperatures between $0{ }^{\circ} \mathrm{C}$ and $50{ }^{\circ} \mathrm{C}$. The selected samples must be large and show no signs of infection and be taken directly to our laboratory to start the experiments.
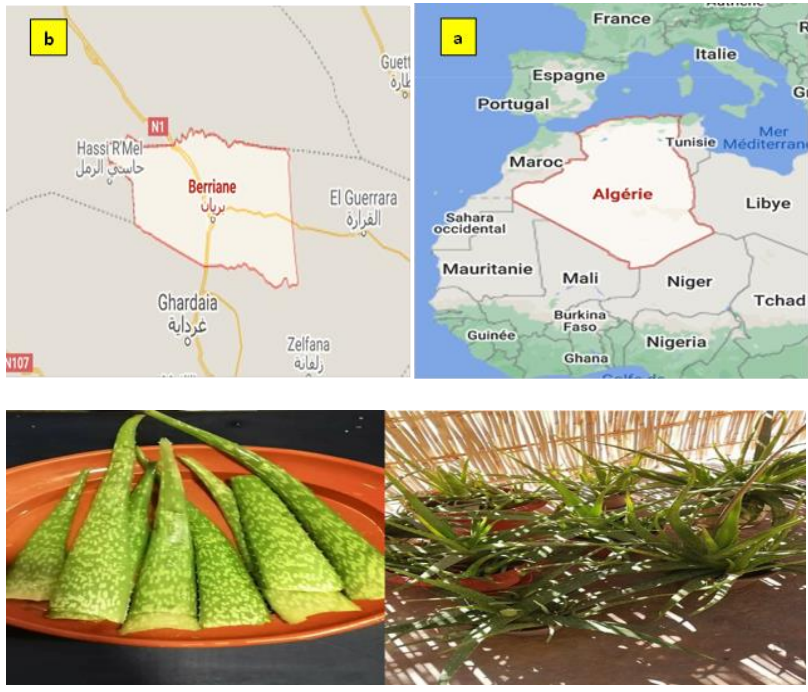

Figure 1 locations where Aloe Barbadensis Miller L. was collected in the district of Berriane, Ghardaia (Google Mapp, 2021).

The fresh Aloe vera leaves were washed many times with cold distilled water to eliminate the dust and impurities and then allowed to dry. After that, we used a knife to fillet and recuperate the mesophyll gel from a middle of the aloe vera leaf, which was homogenized for $15 \mathrm{~min}$ using a household bender. Finally, the mixture was powdered by drying in an oven at $45^{\circ} \mathrm{C}$ for five days.

For preparing an aqueous extract of the gel of Aloe vera leaves, $50 \mathrm{~g}$ of obtained Aloe vera dry powder was extracted using the cold maceration method [36] in 150 $\mathrm{ml}$ of distilled water with continuous shaking for $24 \mathrm{~h}$. After incubation, the mixture was filtered using Whatmann's filter and then evaporated at $50{ }^{\circ} \mathrm{C}$ in a thermostatic water bath to yield the extract.

A methanolic extract of gel from Aloe vera leaves was prepared by extracting $50 \mathrm{~g}$ of the dried powder in 150 $\mathrm{ml}$ of methanol under constant agitation for 24 hours. After incubation, the mixture was filtered using Whatmann's filter and then evaporated using a rotator vacuum evaporator to eliminate the solvent and process the extract. The two extracts were preserved at $4{ }^{\circ} \mathrm{C}$ in sterile dark flasks for any further investigation.

\subsection{Qualitative and quantitative test of aloe vera L. gel extract}

The aqueous and methanolic Aloe vera $L$. gel extract using to determine the qualitative and properties of this plant such as $\mathrm{pH}$, density, water and dry biomass soluble and to investigate the presence of phytochemical compounds including total phenol, flavonoids, alkaloids, saponin, and tannin was calculated. The analyses were carried out using spectrophotometric method according to the standard method with slight modifications [37-39] as stated in table 1. 
Table 1. Physicochemical and phytochemical test.

\begin{tabular}{|c|c|c|c|}
\hline & test & \multicolumn{2}{|l|}{ Reference } \\
\hline \multirow{4}{*}{$\begin{array}{l}\text { Physico- } \\
\text { chemical test }\end{array}$} & $\mathrm{pH}$ & \multicolumn{2}{|c|}{ with $\mathrm{pH}$-metre } \\
\hline & density & \multicolumn{2}{|l|}{ [40] } \\
\hline & water & \multicolumn{2}{|l|}{ [41] } \\
\hline & dry biomass & \multicolumn{2}{|l|}{$[42]$} \\
\hline \multirow{7}{*}{$\begin{array}{l}\text { Quantitative } \\
\text { phytochemical } \\
\text { test }\end{array}$} & Test & Reference & $\begin{array}{l}\text { standard } \\
\text { solution }\end{array}$ \\
\hline & $\begin{array}{l}\text { Phenolic } \\
\text { mg of } \\
\text { GAE/g of } \\
\text { extract }\end{array}$ & [43] & gallic acid \\
\hline & $\begin{array}{l}\text { Flavonoid } \\
\text { mg QE/g of } \\
\text { dry weight }\end{array}$ & {$[44]$} & Quercetin \\
\hline & $\begin{array}{l}\text { Tannin mg } \\
\text { of GAE/g of } \\
\text { extract }\end{array}$ & {$[45]$} & gallic acid \\
\hline & Alkaloid & {$[46]$} & / \\
\hline & $\begin{array}{l}\text { Total } \\
\text { Saponin }\end{array}$ & {$[47]$} & / \\
\hline & Terpenoid & [48] & / \\
\hline
\end{tabular}

\subsection{Antioxidant capacity analysis}

In this study, we used DPPH free radical scavenging method to examine the antioxidant activity of Aloe vera L. gel extract according the protocol used by BrandWilliams et al. [49]. The results was giving with the percentage inhibition of free radical DPPH (I \%) and IC50 value which indicated the concentration of the tested extract that could inhibit $50 \%$ of the DPPH radicals. The Lower concentration indicates higher antioxidant activity activity [50].

\subsection{Antimicrobial activity Test}

By utilising the paper-disc agar diffusion method, the antimicrobial activity of the aqueous extract of Aleo vera gel was examined against one gram positive bacteria (Staphylococcus aureus ATCC 25923), two gram negative bacteria (Pseudomonas aeruginosa ATCC 27853, Escherichia coli ATCC 25922), and one yeast (Candida albicans ATCC 10231). The typical antibiotic Gentamycine (10 g /disc) and Nystatine (100 g /disc) were utilized as the reference test against the bacteria and fungi, respectively [51].

\section{RESULTS AND DISCUSSION}

\subsection{Qualititative and quantitative proprieties of Aloe vera gel extract}

\subsubsection{Physiochemical results}

Table 2. physicochemical propriety of Aloe vera gel extact

\begin{tabular}{|c|c|c|c|}
\hline & $\mathrm{pH}$ & $\begin{array}{c}\text { water content } \\
\text { (\%) }\end{array}$ & $\begin{array}{c}\text { Dray matter } \\
\text { (\%) }\end{array}$ \\
\hline $\begin{array}{l}\text { Aloe vera gel } \\
\text { extract }\end{array}$ & 4.97 & 96.778 & 3.222 \\
\hline
\end{tabular}

The $\mathrm{pH}$ is one of the three parameters used usually for the evaluation and the identification of the commercial gel of aloes. According to table (05), the $\mathrm{pH}$ of the gel extract is 4.97 and the high acidity of gel probably because the accumulation of organic acid likes malic acid [53].

As shown in the table 2, the aloe vera gel was very rich with water $96.778 \%$ and the dry matter content was estimated at $3.222 \%$. These results are logical and confirm that the leaf of Aloe vera is composite a high amount of water [5].

\subsubsection{Phytochemical compounds of the of Aloe barbadensis gel extract}

Table 3. phytochemical propriety of Aloe vera gel extact

\begin{tabular}{|ll|}
\hline Test & Result \\
\hline Total Phenolic $(\mathrm{mg} \mathrm{GAE} / \mathrm{g})$ & $36.25 \pm 0.8$ \\
\hline Total Flavonoid $(\mathrm{mg} \mathrm{QE} / \mathrm{g})$ & $63.26 \pm 0.62$ \\
\hline Tannin $(\mathrm{mg} \mathrm{GAE} / \mathrm{g})$ & $6.29 \pm 0.23$ \\
\hline Alkaloid $(\mathrm{mg} / \mathrm{g})$ & $24.89 \pm 0.79$ \\
\hline Total saponin $(\mathrm{mg} / \mathrm{g})$ & $8.23 \pm 0.65$ \\
\hline Terpenoid $(\mathrm{mg} / \mathrm{g})$ & $14.56 \pm 19$ \\
\hline
\end{tabular}

Mean value \pm Standard error

According the table 2, the result of phytochemical screening test shows that the fresh Aloe vera gel extract obtained by maceration was very rich with bioactive compounds such as phenol, flavonoid, tannin, alkaloid, saponin and terpenoid.

The total flavonoid content is the highest secondary metabolite compound found it the aloe vera gel extract with $63.26 \pm 0.62 \mathrm{mg} \mathrm{QE} / \mathrm{g}$ and this value is very close to the value founding by Taukoorah and Mahomoodally [54].

A. barbadensis gel extract was found to have a good amount of total Phenol to be $36.25 \pm 0.8 \mathrm{mg} \mathrm{GAE} / \mathrm{g}$. This 
result is in accordance with the recent investigation performed by Kumar et al. [6] where the values the total phenol levels ranging from 32 to $65 \mathrm{mg} \mathrm{GAE} / \mathrm{g}$ of dry. [56]

From the data, we can observed that our extract contain a appreciable amounts of alkaloid $(24.89 \pm 0.79 \mathrm{mg} / \mathrm{g})$ and terpenoid $(14.56 \pm 19 \mathrm{mg} / \mathrm{g})$, which is near to the values founding by Sonam and Archana to be $23.83 \pm 0.28 \mathrm{mg} / \mathrm{g}$ and $\mathrm{mg} / \mathrm{g} 13.5 \pm 0.86$, respectively [57].

This study showed total tannin content in the Aleo gel extract to be $6.29 \pm 0.13 \mathrm{mg} \mathrm{GAE} / \mathrm{g}$, and this amount is higher than the result founding in the study done by $\mathrm{R}$. Bista et al. to be $1.13 \pm 0.19 \mathrm{mg} \mathrm{GAE} / \mathrm{g}$ [58].

The difference in the amount of secondary metabolites contained in the A. barbadensis gel extract obtained from Ghardaia compared with another country, as reported in an earlier study, depended on the variation of the age of the plant, climatic conditions and environmental factors [59].

\subsection{Antioxidant activity}
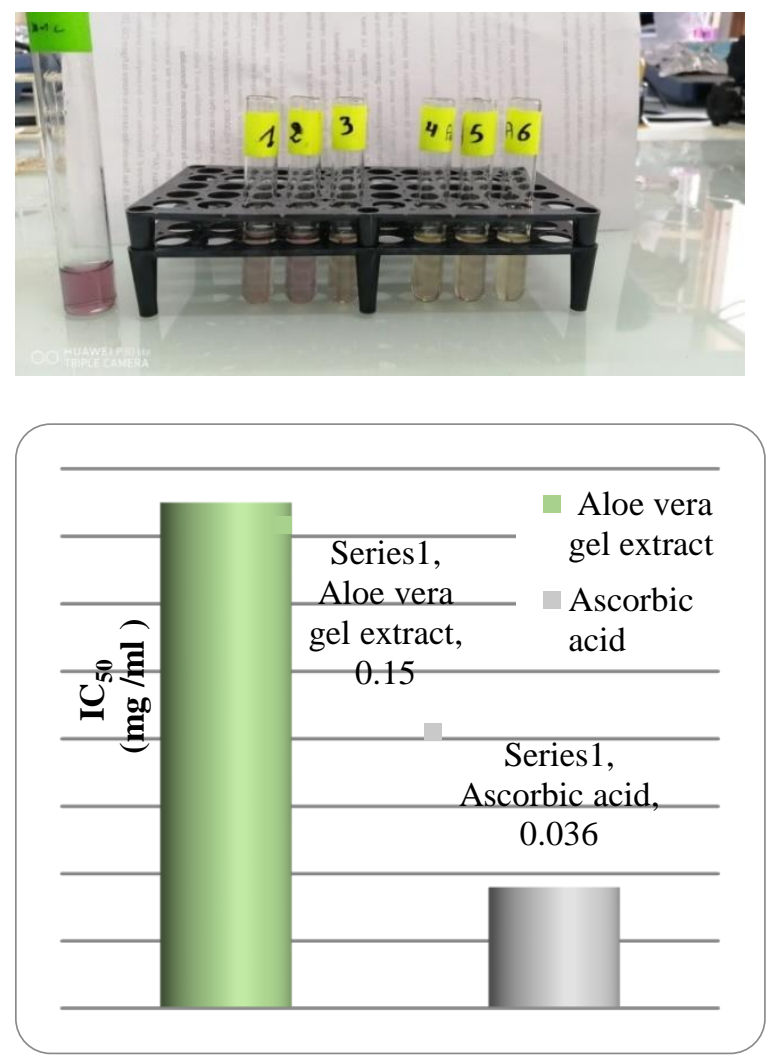

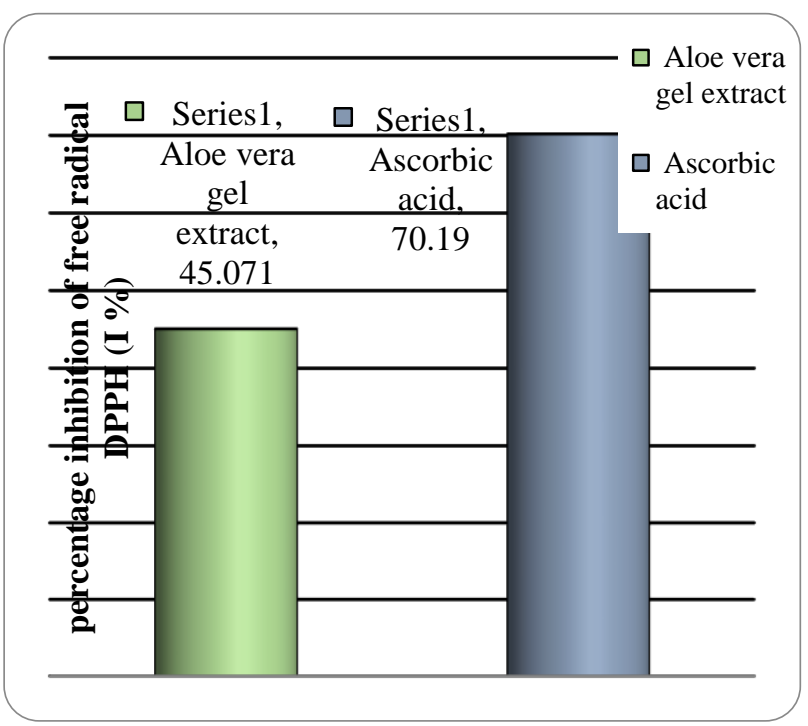

Figure 2 Results of antioxidant capacity of aloe vera gel extract.

The antioxidant potential test using DPPH radical method (Fig 2) was determined that our gel extract showed a significant antioxidant activity by reducing $45,071 \%$ of radical DPPH with $\mathrm{IC}_{50}$ of $0.15 \mathrm{mg} / \mathrm{mL}$. Furthermore, this extract exhibit a effective antioxidant power but it's was lower compared with standard antioxidant (ascorbic acid).

This antioxidant efficiently can be related to the inclusion of bioactive molecule like flavonoids and phenolic acids [60] [61].

\subsection{Antimicrobial activity}

The capacity antifungal and antibacterial of the Aloe vera gel extract was evaluated using disc diffusion method technique against different pathogenic microbes' four pathogenic bacteria and one fungi as reported in the table 4.

Table 4. Inhibition zone of tested simple against different strains

\begin{tabular}{|c|c|c|c|c|}
\hline & \multirow{2}{*}{$\begin{array}{l}\text { Gra } \\
\mathrm{m}\end{array}$} & \multirow{2}{*}{$\begin{array}{l}\text { Aloe- } \\
\text { vera gel } \\
\text { extract }\end{array}$} & \multicolumn{2}{|l|}{ antibiotic } \\
\hline & & & Gentamycine & $\begin{array}{l}\text { nystati } \\
\text { ne }\end{array}$ \\
\hline E. coli & - & $15 \pm 0.15$ & $22 \pm 0.12$ & 1 \\
\hline $\begin{array}{l}\text { P. } \\
\text { aerugino } \\
\text { sa }\end{array}$ & - & - & $21 \pm 0.2$ & / \\
\hline S. aureus & + & $8 \pm 0.04$ & $25.5 \pm 17$ & 1 \\
\hline $\begin{array}{l}\text { C. } \\
\text { albicans }\end{array}$ & $\begin{array}{l}\text { fung } \\
\text { i }\end{array}$ & $6 \pm 0.12$ & $33 \pm 54$ & $15 \pm 0.1$ \\
\hline
\end{tabular}

Zone of inhibition=mean Values $\pm S D(\mathrm{~mm})$,

(-): No zone of inhibition 
The extract was showed an inhibitory zone between 6 and $15 \mathrm{~nm}$, and this indicated that the aloe gel extract revealed a highest antibacterial capability against the $E$. coli gram negative bacteria with zone of inhibition around $15 \pm 0.15$ $\mathrm{mm}$ which was lower than Gentamycine the standard antiobiotic. The two other strain $S$. aureus and $P$. aeruginosa showed a resistance to our tested extract, then Aloe vera gel extract can't inhibit the growth of this two bacteria. In the other side, the aloe vera gel extract revealed a weak antifungal activity against $C$. albicans. Same results was reported in the research of Darshan $\mathrm{T}$ Dharajiya et al. [62]. This antibacterial ability of Aloe barbadensis gel extract agins E.coli could be attributed to the presence of photochemical activity including phenol, flavonoid, alkaloids, saponins and tannins which were reported to prevent several diseases [63].

\section{CONCLUSION}

The presence of the phytochemical compounds such as phenol, flavonoid, tannin, alkaloid, saponin and terpenoid in the Aloe barbadensis gel extract give this plant significant therapeutic and pharmacology properties as reported in literature before. These phytochemical constituents can be extract and used for the development of drugs with antimicrobial, antiviral, anti-inflammatory, antioxidant anti-cancer activity.

\section{REFERENCES}

[1] J.S. Halles, A drug for all seasons, Medical and pharmacological history of aloe, Bull N Y Acad Med.66 (6) (1990) 647-59.

[2] C. Egbuna, E. Gupta, S. M. Ezzat, J. Jeevanandam, et al., Aloe Species as Valuable Sources of Functional Bioactives Functional Foods and Nutraceuticals, chapter: 18, Springer , 2020. Publisher.DOI: 10.1007/978-3-030-42319-3_18

[3] I.E. Cock, An updated review of the phytochemistry and therapeutic uses of plants of the genus Aloe, Pharmacognosy Communications 6(1) (2016) 52.

[4] O. Grundmann, B Pharm,ms,PHD, Aloe Vera Gel Research Review, Natural Medicine Journal, Vol. 4 Issue 9, 2012.

[5] M.D. Boudreau, F.A. Beland, An evaluation of the biological and toxicological properties of Aloe barbadensis (miller), Aloe vera, J Environ Sci Health C, Environ Carcinog Ecotoxicol Rev. 24(1) (2006) 103-54.

[6] Y. Ni, D. Turner, K.M. Yates, I. Tizard, Isolation and characterization of structural components of Aloe vera L. leaf pulp. Int Immunopharmacol, 20; 4(14) (2004) 1745-55. doi: 10.1016/j.intimp.2004.07.006.
[7] M. Schweizer, Aloe the health and healing plant, 4th edition, 1st English edition translated by Ed Maykut, APB, ISBN 2-912978-08-4,1994. http://www.aloeinfo.info/aloeangl66.pdf.

[8] M. Tanaka, M. Yamada, T. Toida, K. Iwatsuki, Safety evaluation of supercritical carbon dioxide extract of Aloe vera gel, J Food Sci. 77(1) (2012) T2-9. doi: 10.1111/j.1750-3841.2011.02452.x.

[9] T. Reynolds, A.C. Dweck, Aloe vera leaf gel, a review updated, J Ethnopharmacol, 68 (1999) 3-37. https://doi.org/10.1016/S0378-8741(99)00085-9

[10] E. R. Rodriguez, M. J. Darias, R. C. Diaz, Aloe vera as a functional ingredient in foods, CritRev Food Sci Nutr.50 (2010) 305-326. https://doi.org/10.1080/10408390802544454,

[11] T.H. Mchugh, E. Senesi, Apple wraps: A novel method to improve the quality and extend the shelf lifeof fresh-cut apples, J. Food Sci. 65 (2000) 480 485. 2621.2000.tb16032.x

[12] S.E. Dal'Belo, L.R. Gaspar, P.M. Maia Campos, Moisturizing effect of cosmetic formulations containing Aloe vera extract in different concentrations assessed by skin bioengineering techniques. Skin Res Technol. 12(4) (2006)241-46. doi: 10.1080/10590500600614303.

[13] Cosmetic Ingredient Review Expert Panel, Final report on the safety assessment of AloeAndongensis Extract, Aloe Andongensis Leaf Juice, aloe, Int J Toxicol. 2007;26 Suppl 2:1-50. doi: 10.1080/10915810701351186.

[14] S. Arunkumar, and M. Muthuselvam, Analysis of phytochemical constituentsand antimicrobial activities of Aloe vera L. against clinical pathogens, World J. Agri. Sci., 5(5) (2009) 572-576.

[15] F. Nejatzadeh-Barandozi, Antibacterial activities and antioxidant capacity of Aloe vera, Organic and Medicinal Chemistry Letters. , 3 (2013) 5.

[16] U. Sitara, N. Hassan, J. and Naseem,. Antifungal activity of Aloe vera gelagainst plant pathogenic fungi. Pakistan J. Botany, 43(4) (2011) 2231-2233.

[17] K. Zandi, M.A. Zadeh, K. Sartavi, and Z. Rastian,. Antiviral activity of Aloe vera against herpes simplex virustype 2: An in vitro study, African J. Biotechnol., 6(15) (2007) 1770-1773.

[18] J. Reuter, A. Jocher, J. Stump, B. Grossjohann, G. Franke, C.M.Schempp, Investigation of the antiinflammatory potential of Aloe vera gel $(97.5 \%)$ in the ultraviolet erythema test. Skin Pharmacol Physiol. 21(2) (2008)106-10. 
[19] R.H. Davis, J.J. Donato, G.M. Hartman, R. C.Haas, Anti-inflammatory and wound healing activity of a growth substance in Aloe vera, J Am Podiatr Med Assoc., 84 (2) (1994)77-81.

[20] A. Ray, S.D. Gupta, and S. Ghosh, Evaluation of anti-oxidative activity andUV absorption potential of the extractsof Aloe vera L. gel from differentgrowth periods of plants, IndustrialCrops and Products , 49 (2013) 712-719.

[21] M. Shalabi, K. Khilo, M.M. Zakaria, M.G. Elsebaei, W. Abdo, and W. Awadin, Anticancer activity of Aloe vera and Calligonum comosum extractsseparetely on hepatocellular carcinomacells, Asian Pacific J. Tropical Biomedicine , 5(5) (2015) 375-381.

[22] Y.S. Keum, K.K. Park, J.M. Lee, K.S. Chun, J.H. Park, S.K. Lee, H. Kwon, Y.J. Surh, Antioxidant and anti-tumor promoting activities of the methanol extract of heatprocessed ginseng, Cancer Lett, 150 (2000) 41-48.

[23] R. Srihari, A.R.Surendranath, N. Kasturacharya, K.C.Shivappa, N.D.Sivasitambaram, and B.L. Dhananjaya, Evaluating the cytotoxic potential of methonolic leaf extract of

Aloe vera on MCF-7 breast cancer celllines Int. J. Pharmacy and Pharmaceutical Sci., 7(13) (2015) 8183.

[24] V. Thamlikitkul, N. Bunyapraphatsara, W. Riewpaiboon, S. Theerapong, C. Chantrakul, T.Thanaveerasuwan,Clinical trial of aloe vera Linn. for treatment of minor burns, Siriraj Hosp Gaz. 43(5) (1991) 313-316.

[25] V. Visuthikosol, B. Chowchuen, Y. Sukwanarat, S. Sriurairatana, V. Boonpucknavig, Effect of aloe vera gel to healing of burn wound a clinical and histologic study, J Med Assoc Thai., 78(8) (1995) 403-09.

[26] M.A. Akhtar, S.K.Hatwar, Efficacy of aloe vera extract cream in management of burn wound, J Clin Epidemiol., 49:24(1996).

[27] A.D. Vardy, A.D. Cohen, T. Tchetov, A doubleblind, placebo-controlled trial of Aloe vera (A. barbadensis) emulsion in the treatment of seborrheic dermatitis, J Derm Treatment. 10(1) (1999) 7-11

[28] R.H. Davis, J.M. Kabbani, N.P. Maro, Aloe vera and wound healing, J Am Podiatr Med Assoc 77 (1987)165-169.

[29] J. Roesler, C. Steinmuller, A. Kiderlen, A. Emmendorffer, H. Wagner, M.L.LohmannMatthes, Application of purified polysaccharides from cell cultures of the plant Echinacea purpurea to mice mediates protection against systemic infections with Listeria monocytogenes and Candida albicans, Int J Immunopharmacol. 13 (1991) 27-37.

[30] C.A. Lans Ethnomedicines used in Trinidad and Tobago for urinary problems and diabetes mellitus, J Ethnobiol Ethnomed., 2 (2006)45.

[31] P. Chatterjee, B. Chakraborty, and S. Nandy, Aloe vera plant: review withsignificant pharmacological activities, Mintage J. Pharmaceutical and Med.Sci, 2(3) (2013) 21-24.

[32] A. Surjushe, R.Vasani, and D.G.Saple,

Aloe vera: A short review, Indian J. Dermatol., 53(4) (2008)163-166.

[33] Y. Ni, D. Turner, K.M. Yates, I. Tizard, Isolation and characterization of structural components of Aloe vera L. leaf pulp. Int Immunopharmacol, 20; 4(14) (2004) 1745-55. doi: 10.1016/j.intimp.2004.07.006.

[34] A. Peirce, The American pharmaceutical association practical guide to natural medicines, Vol 1. First ed: William Morrow, 1999.

[35] I. Kahramanoglu,C. Chen, J. Chen, C. W. Chunpeng, Chemical Constituents, Antimicrobial Activity, and food preservative characteristics of Aloe vera gel, Agronomy., 9(12) (2019) 831. DOI: 10.3390/agronomy9120831

[36] D. Dharajiya, P. Patel, M. Patel, and N. Moitra, In vitro antimicrobial activity and qualitative phytochemical analysis of Withania somnifera (L.) Dunalextracts, Int. J. Pharmaceutical Sci. Review and Res., 27(2) (2014) 349-354.

[37] N. Jaradat, F. Hussen, A.A. Ali, Preliminary phytochemical screening, quantitative estimation of total flavonoids, total phenols and antioxidant activity of Ephedra Alata Decne, J. Mater. Environ. Sci. 6(6) (2015) 1771-1778.

[38] D. Dharajiya, N. Moitra, B. Patel, and R.K. Patel, Preliminary phytochemicalanalysis of the Indian medicinal plantsfor antibacterial activity against bovinemastitis pathogens, Wayamba J. Animal Sci.,4: (2012) No. 1342590628.

[39] D.Dharajiya, T. Khatrani, P. Patel, N. Moitra, Evaluation of antifungal activity of Emblicaofficinalis, Aloe vera and Vitex negundo extracts, J. Chemical, Biol. PhysicalSci., 5(4) (2015) 3990-3996.

[40] NF ISO 6883, Normes nationales et documents normatifs nationaux, 2017. 
[41] AFNOR (Association Francaise de Normalisation) Recueil des normes francaises des produits dérivés des fruits et légumes. Jus de fruits, Paris, 327 p 1982.

[42] B. Benzidia, M. Barbouchi, H. Hammouch, N. Belahbib, M. Zouarhi, H. Erramli, et. al., Chemical composition and antioxidant activity of tannins extract from green rind of Aloe vera (L.) Burm. F. Journal of King Saud University - Science, p:1-23 2018.

[43] V.L. Singleton, R. Orthofer, R.M.LamuelaRaventos, Analysis of total phenols and other oxidation substrates and antioxidants by means of Folin Ciocalteau reagent, Methods in Enzymology. 299 (1999)152-178.

[44] M.L. Barek, M. Hasmadi, A.Z. Zaleha, A.B. Mohd Fadzelly, Effect of different drying methods on phytochemicals and antioxidant properties of unfermented and fermented teas from Sabah Snake Grass (Clinacanthus nutans Lind.) leaves, International Food Research Journal., 22(2) (2015) 661-670.

[45] R. Singh, P.K. Verma, G. Singh, Total phenolic, flavonoids and tannin contents in different extracts of Artemisia absinthium, J IntercultEthnopharmacol. 1(2)(2012)101-104.

[46] J.B.Harborne, Phytochemical Methods, Chapman and Hall Ltd., London, 49-188 1973.

[47] B. Obdoni, P. Ochuko, Phytochemical studies and comparative efficacy of the crude extracts of some homostatic plants in Edo and Delta States of Nigeria, Global J. Pure Appl. Sci 8 (2001) 203-208.

[48] N.M. Ferguson, A textbook of Pharmacognosy, Mac Millan Company, Vol. 1911956.

[49] W. Brand-Williams, M.E. Cuvelier, C. Berset, Use of a free radical method to Evaluate Antioxydant Activity. lebensm-Wiss uTechnol, 28 1995) 25-30.

[50] H. Zhao, W. Fan, J. Dong, J. Lu, J. Chen, L. Shan, et al., Evaluation of antioxidant activities and total phenolic contents of typical malting barley varieties, Food Chemistry.,;107(1) (2008) 296-304. https://doi.org/10.1016/j.foodchem.2007.08.018

[51] A. Lakhdari, L. Sakhri, Y. Khane, A. M. Lakhdar, A. Kemassi, N. Bouras, Evaluation of drying effect on the composition of the essential oil isolated from aerial parts of Pituranthos chloranthus from southern Algeria and their biological activities, Biocatalysis and Agricultural Biotechnology, 30101844,2020, DOI: 10.1016/j.bcab.2020.101844

[52] Y-T. Wang, K.J. Strong, A two-year study monitoring several physical and chemical properties of field-grown Aloe barbadensis Miller leaves. Subtropical Plant Sci., 47 (1995)34-38.

[53] U. Taukoorah, M.F. Mahomoodally, Crude Aloe vera gel shows antioxidant propensities and inhibits pancreatic lipase and glucose movement in vitro. Advances in Pharmacological Sciences., p:1-9, 2016.

[54] S. Kumar, A. Yadav, M. Yadav, J.P.Yadav, Effect of climate change on phytochemical diversity, total phenolic content and in vitro antioxidant activity of Aloe vera (L.) Burm.f. BMC Res. Notes. ,10(1) (2017) 60 .

[55] S.K.Sonam and A. Tiwari, Pytochemical evaluation of different Aloe species, International Journal of chemical and pharmaceutical analysis, International Journal of Chemical and Pharmaceutical Analysis, 3(4) (2016)1055

DOI:http://dx.doi.org/10.21276/ijcpa

[56] R. Bista, A. Ghimire, S. Subedi, Phytochemicals and antioxidant activities of Aloe vera (Aloe Barbadensis). J Nut Sci Heal Diet 1(1) (2020) 2536.

http://dx.doi.org/10.47890/JNSHD/2020/RBista/102438 03

[57] S. Kumar, M. Yadav, A. Yadav, J.P.Yadav, Impact of spatial and climatic conditions on phytochemical diversity and in vitro antioxidant activity of Indian Aloe Vera (1.) Burm.f. South African Journal of Botany,111(2017) 50-59.

[58] Z.B. Aljesri.A study on synergistic antimicrobial and antioxidant activities of some pharmaceutical oils and herbal extracts. 2015.

[59] Q. Hu, J. Xu \& Y. Hu, Evaluation of antioxidant potential of Aloe vera (Aloe barbadensisMiller) extracts. J Agri Food Chem51 (2003) 7788-7791.

[60] D. Dharajiya, N. Pagi, H. Jasani, P. Patel, Antimicrobial Activity and Phytochemical Screening of Aloe vera (Aloe barbadensis Miller), Int.J.Curr.Microbiol.App.Sci., 6 (3) (2017) 2152 2162. doi :10.20546/ijcmas.2017.603.246

[61] F. I. Gorsi, T. Kausar, M. A. Murtaza, Evaluation of antibacterial and antioxidant activity of Aloe vera(Aloe barbadensis Miller) gel powder using different solvents, Pure Appl. Biol., 8(2) (2019) 1265-1270.

http://dx.doi.org/10.19045/bspab.2019.80068 